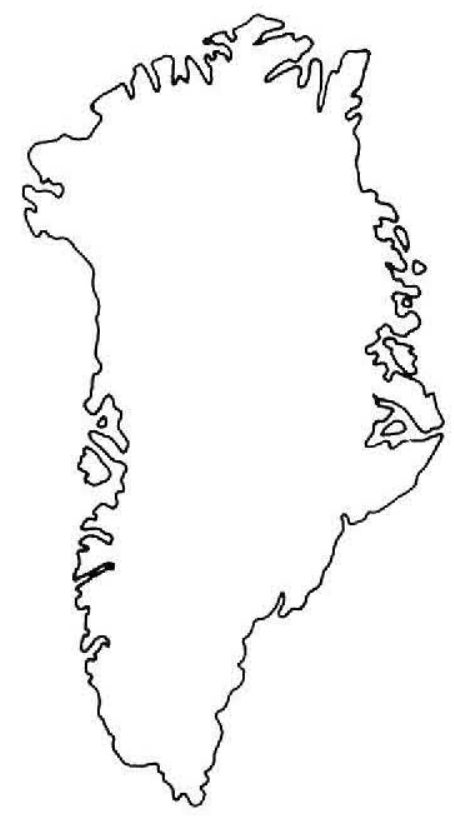

\title{
Blue cancrinite from South-East Greenland
}

\author{
Aage Jensen and Troels F. D. Nielsen
}

\begin{abstract}
Blue cancrinite intergrown with sodalite and albite has been found in nepheline syenite dykes in the Precambrium of South-East Greenland. Cabochons cut of the material show a blue colour with more or less pronounced aventurescence. Electron microprobe analyses and $\mathrm{X}$-ray investigation have been carried out to establish the position in the cancrinite-vishnevite solid solution series. Trace elements have been determined by spectral analysis of the Greenland cancrinite as well as cancrinite from Litchfield, Maine, USA and Bancroft, Ontario, Canada.
\end{abstract}

Aa. J., Geological Institute, University of Copenhagen, Øster Voldgade 10, DK-1350 Copenhagen K, Denmark.

T. F. D. N., Geological Survey of Greenland. Oster Voldgade 10, DK-1350 Copenhagen K, Denmark.

Cancrinite, as gem material, is known in a yellow variety from Litchfield, Maine, USA and a rose-coloured variety from Bancroft, Ontario, Canada, but recently an occurrence of a member of the cancrinite-vishnevite solid solution series with a blue colour was found in SouthEast Greenland. This blue variety is a potential gemstone.

\section{Location and occurrence}

Blue cancrinite (Fig. 1) forms late crystallized masses in nepheline syenite dykes in the carbonatite-nephelinite 'Singertat' complex of the Archaean Skjoldungen Alkaline Province in South-East Greenland (Nielsen \& Rosing, 1990). The Skjoldungen Alkaline Province was only recognized in 1987 and has not yet been investigated in detail but appears to represent a syn- to post-tectonic alkaline province emplaced at the transition between a
Fig. 1. Raw blue cancrinite and greyish-white sodalite from the 'Singertat' complex, South-East Greenland. Coin $(3 \mathrm{~cm}$ diameter) for scale.

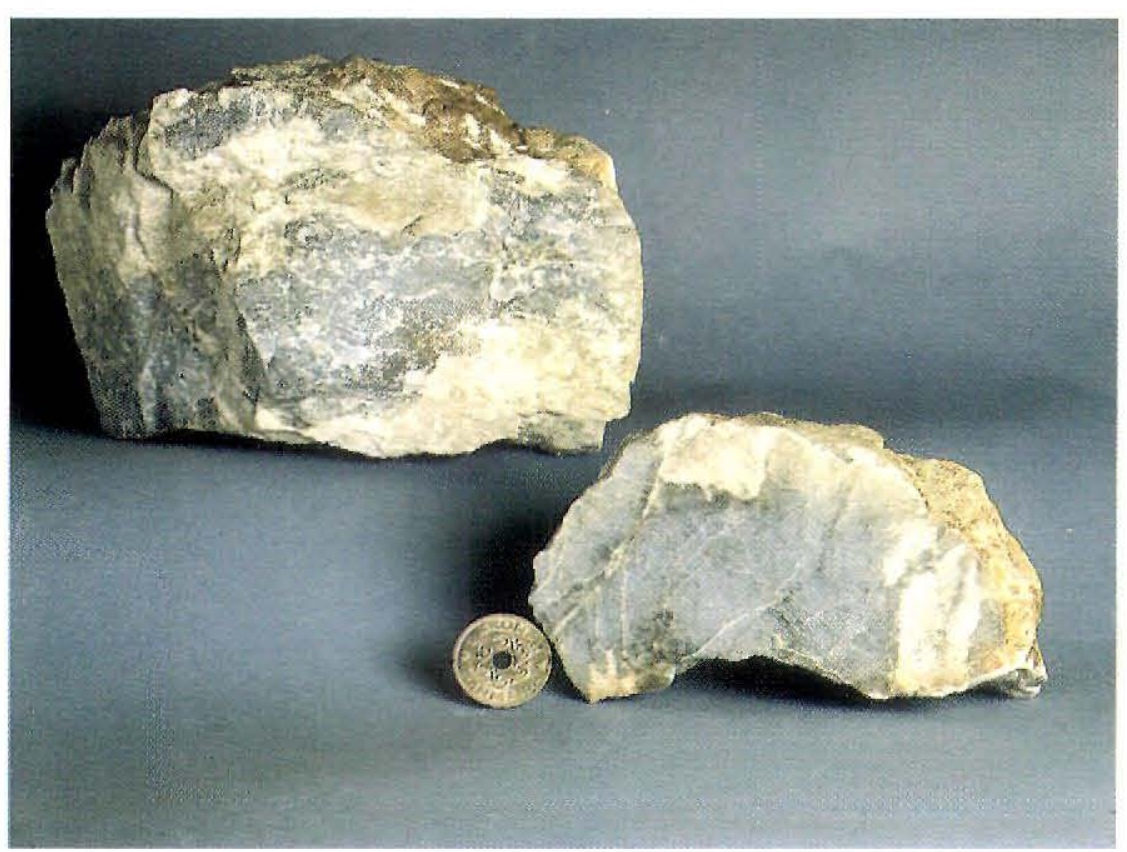




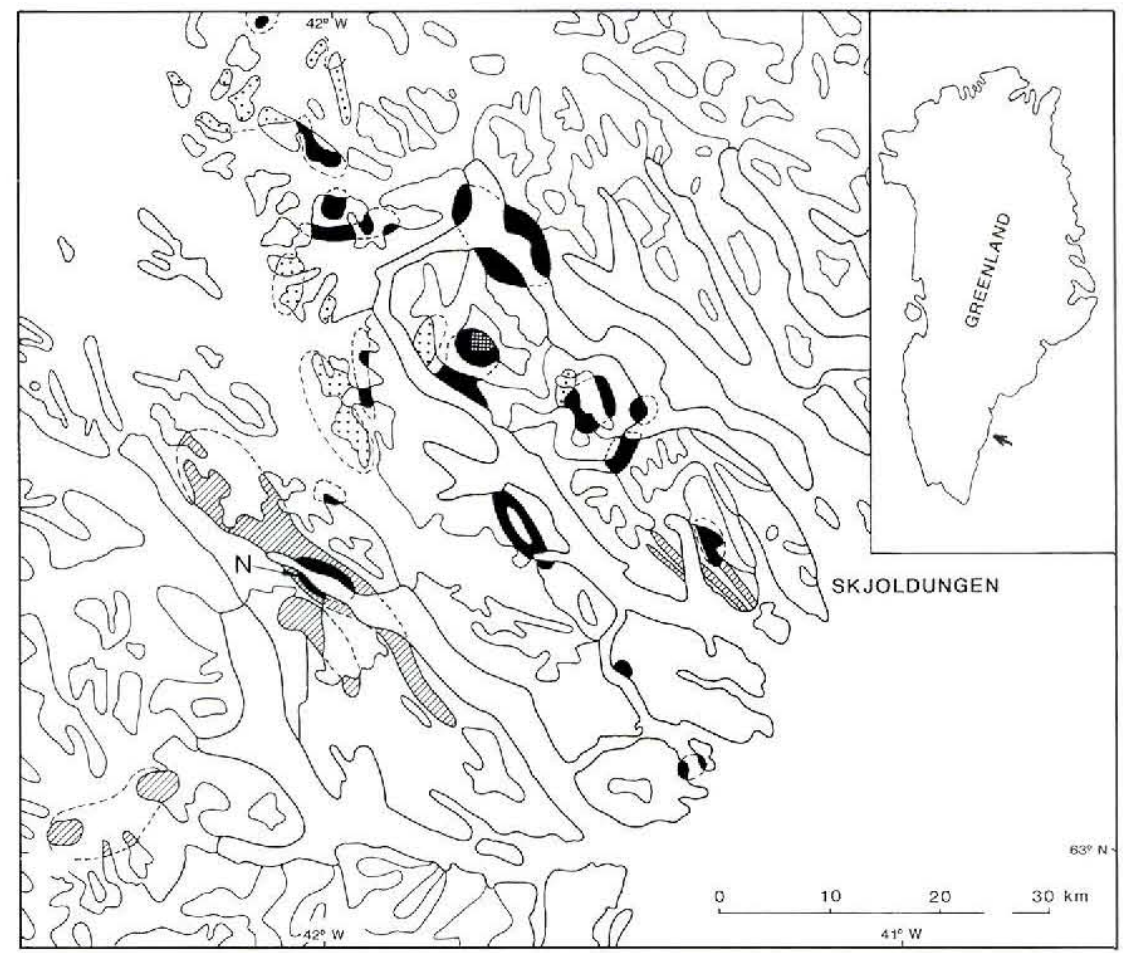

Fig. 2. The occurrence of alkaline gneisses and complexes of the Skjoldungen Alkaline Province in the Skjoldungen area, South-East Greenland. Ruled: alkaline gneisses, black: mafic to ultramafic alkaline complexes and the nephelinitic 'Singertat' Complex (N); crosshatched: dioritic to syenitic complex; cross: syenitic to granitic complexes (after Nielsen \& Rosing, 1990).

southern block of mainly agmatitic gneisses and another block of mainly non-agmatitic gneisses and supracrustal belts (Escher, 1990). Preliminary age determinations have given ages between $2800 \mathrm{Ma}$ and $2675 \mathrm{Ma}$ for the alkaline rocks (Nielsen \& Rosing, 1990).

Nielsen \& Rosing noted that the chemistry and mineralogy as well as the mode of emplacement suggests that the Skjoldungen Alkaline Province may best be compared to the Halliburton-Bancroft province in Canada and the Seiland province in Norway. The majority of the complexes in the Skjoldungen Alkaline Province are mildly undersaturated rocks forming nepheline normative gabbros, monzogabbros, monzonites, syenites and quartz syenites. Related basaltic to andesitic dykes show up to $c$. $5 \%$ normative nepheline. The only strongly undersaturated rocks are found in the carbonatite-nephelinite 'Singertat' complex in which the occurrence of blue cancrinite is found.

The 'Singertat' complex is located at $63^{\circ} 14^{\prime} \mathrm{N}$, $42^{\circ} 00^{\prime} \mathrm{W}$ at the head of the fjord Kagtertôq (Kagssortôq) just south of Skjoldungen island. Access to the complex is difficult as the fjord is blocked midway by the glacier Skinfaxe. The complex is located in a deeply eroded and sediment-covered area at the head of the fjord (Fig. 2). Very limited exposures can be found on the shore that is covered by Quaternary sediments and, by Greenlandic standards, luxurious vegetation. A gravimetric survey has defined the limits of the complex below sea level. The complex is oval in shape $(4 \times 1.5 \mathrm{~km})$ and is estimated to cover an area of c. $5 \mathrm{~km}^{2}$. Metasomatized gneisses are found surrounding the complex and in isolated areas in the vicinity of the complex.

The intrusive rocks of the complex are simple and composed of nepheline, alkali pyroxene and/or amphibole, in the more mafic rocks biotite/phlogopite and in the more felsic rocks albite-rich plagioclase is also present. Very few accessory phases have been noted; these include apatite, calcite and rare zircon and sulphide minerals. The most mafic varieties may be termed melteigites whereas the most nepheline-rich types may be termed urtites. The complex was emplaced late in the tectonic development of the region and at the NW contact nephelinitic melts were emplaced into active NW-SE shear zones. The shearing led to chemical interaction and formation of less undersaturated nepheline syenite and syenitic rocks. Many of these are sheared and transformed into nepheline syenite mylonites comparable to those of the Seiland province (Brian Robins, personal communication, 1989).

The ijolites are intruded by a suite of dykes, including nephelinites, syenites and carbonatites. Although exposures are limited the dykes in the eastern part of the complex appear to show a concentric pattern whereas the dykes in most other parts of the complex show no preferred mode of emplacement. 
Fig. 3. The southern side of the fjord Kangertôq (Kagssortôq) seen from the centre of the 'Singertat' complex.

Photographed shortly before midnight in the month of July. The cancrinite-bearing dyke is exposed in the middle ground at sea level on the opposite side of the bay.

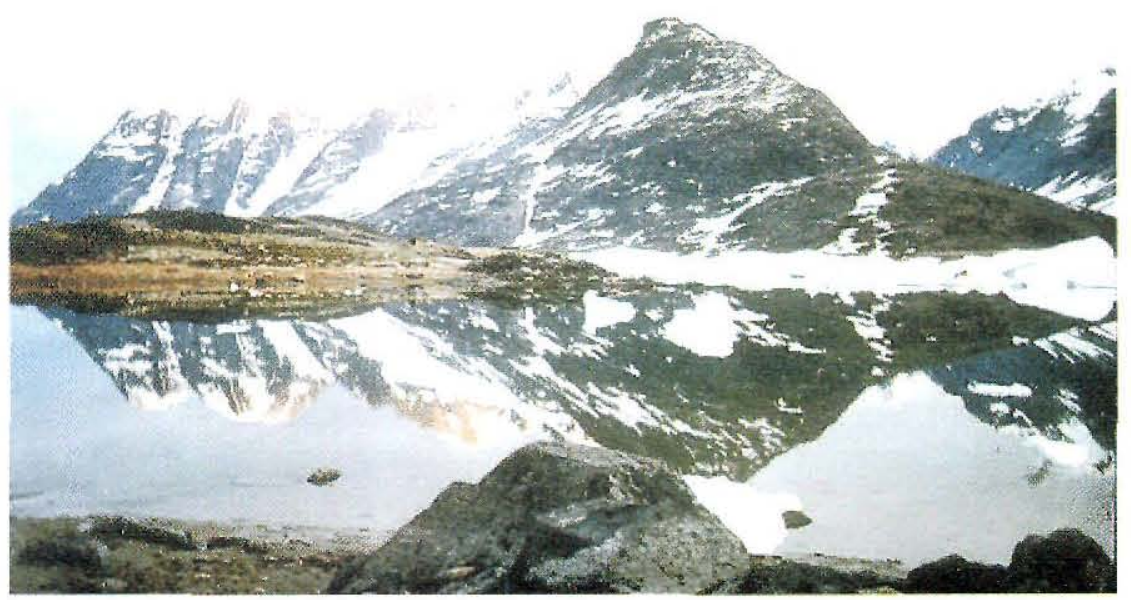

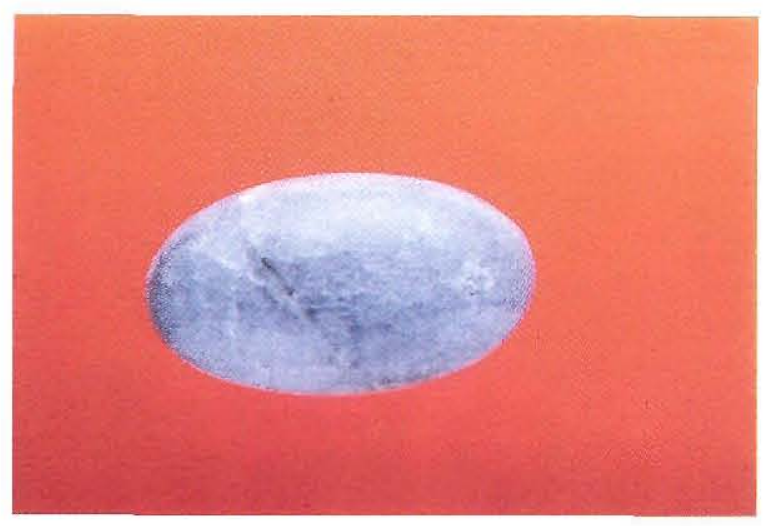

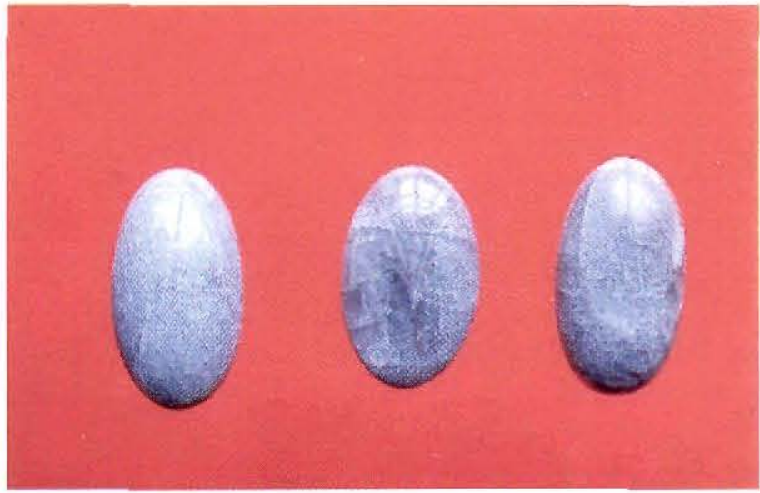

Fig. 4 top. Cabochon of blue cancrinite. $4.0 \times 2.3 \mathrm{~cm}(57.11 \mathrm{ct})$. Fig. 4 bottom. Three cabochons of blue cancrinite. Approximately $2.3 \times 1.3 \mathrm{~cm}$ (the one in the middle is only $2.1 \times 1.3 \mathrm{~cm}$ ). Between 10 and $14 \mathrm{ct}$.

\section{The cancrinite-bearing dyke}

The blue cancrinite was collected from a more than 30 $\mathrm{cm}$ wide dyke composed of coarse crystals of albitic plagioclase in a mass of blue cancrinite and white to grey sodalite. The dyke only outcrops over a few metres on the shore of the fjord (Fig. 3). Most of the cancrinite was collected as loose blocks close to the exposure. The dyke trends approximately E-W, but no continuation could be seen under the sediments and vegetation. Massive blue cancrinite and greyish-white sodalite dominate the dyke.

All the nepheline syenite dykes and pegmatites in the 'Singertat' complex are composed of nepheline, alkali pyroxene and amphibole, minor biotite and albite-rich plagioclase. Accessory phases include apatite, calcite and rare zircon. Blue cancrinite is found in most dykes and pegmatites either as an alteration product of nepheline (due to reaction with late stage $\mathrm{CO}_{2}$-rich fluid) or as an interstitial mass crystallized from late stage $\mathrm{CO}_{2}$-rich melt. The blocks with blue cancrinite and sodalite are believed to represent the latter type. Alternatively, the cancrinite masses could represent replacement pegmatites.

\section{Description}

The Greenland cancrinite occurs intergrown with sodalite and albite with a grain size about $0.3 \mathrm{~mm}$ and has inclusions of calcite, pyrite, hematite, rutile and mica. Sodalite and albite are whitish grey whereas the cancrinite is light to medium blue. Cabochons always show a more or less pronounced white aventurescence, probably caused by the calcite inclusions (Fig. 4).

Refractometer measurements show that the cancrinite 
Table 1. Electron microprobe analyses of the cancrinite-vishnevite from Greenland (GGU sample 323673)

\begin{tabular}{|c|c|c|c|c|c|c|c|}
\hline \multirow{2}{*}{$\frac{\text { Oxide }}{\mathrm{SiO}_{2}}$} & \multirow{2}{*}{\multicolumn{3}{|c|}{$\frac{\text { Wt. \% }}{34.88}$}} & \multicolumn{4}{|c|}{ Number of ions on the basis of $\mathrm{Si}+\mathrm{Al}=12$} \\
\hline & & & & $\mathrm{Si}$ & 6.042 & 6.137 & 6.068 \\
\hline $\mathrm{Al}_{2} \mathrm{O}_{3}$ & 28.79 & 28.48 & 28.94 & $\mathrm{Al}$ & 5.958 & 5.863 & 5.932 \\
\hline $\mathrm{FeO}$ & 0.00 & 0.00 & 0.00 & $\mathrm{Fe}$ & 0.000 & 0.000 & 0.000 \\
\hline $\mathrm{CaO}$ & 085 & 0.97 & 0.97 & $\mathrm{Ca}$ & 0.158 & 0.179 & 0.178 \\
\hline $\mathrm{Na}_{2} \mathrm{O}$ & 21.69 & 21.96 & 21.89 & $\mathrm{Na}$ & 7.381 & 7.450 & 7.386 \\
\hline $\mathrm{K}_{2} \mathrm{O}$ & 0.92 & 0.87 & 0.79 & $\mathrm{~K}$ & 0.211 & 0.189 & 0.178 \\
\hline $\mathrm{Cl}$ & 0.00 & 0.00 & 0.00 & $\mathrm{Cl}$ & 0.000 & 0.000 & 0.000 \\
\hline \multirow[t]{2}{*}{$\mathrm{SO}_{3}$} & 7.07 & 6.97 & 7.04 & $S$ & 0.928 & 0.914 & 0.921 \\
\hline & 93.75 & 94.37 & 94.51 & & 20.678 & 20.732 & 20.663 \\
\hline
\end{tabular}

The electron microprobe analyses were carried out using a JEOL 733/Superprobe with a TRACOR Northern energy dispersive system. The following standards were used $\mathrm{Na}$, albite; $\mathrm{Al}$, corundum; $\mathrm{Si}$ and $\mathrm{Ca}$, wollastonite; $\mathrm{K}$, orthoclase; $\mathrm{Fe}$, hematite; $\mathrm{Cl}$, sodalite and $\mathrm{S}$, barite.

has an omega value of 1.499 and an epsilon value of 1.493 with a birefringence of 0.006 . The density varies between 2.42 and 2.44. Hardness is between 5 and 6 .

When exposed to short-wave ultraviolet radiation the cancrinite fluoresces dark red to purple, and exposed to long-wave ultraviolet radiation the cancrinite fluorescence is dark violet. In the spectroscope there is an absorption band from the red end of the spectrum until $650 \mathrm{~nm}$, and another absorption band from the blue end until $440 \mathrm{~nm}$.

The cancrinite effervesces in hot diluted hydrochloric acid.

\section{Chemical composition}

The cancrinite-vishnevite solid solution series comprises all compositions intermediate between the cancrinite end-member

$(\mathrm{Na}, \mathrm{Ca})_{7-8} \mathrm{Al}_{6} \mathrm{Si}_{6} \mathrm{O}_{24}\left(\mathrm{CO}_{3}, \mathrm{SO}_{4}, \mathrm{Cl}\right)_{1,5-2.0} \cdot 1-5 \mathrm{H}_{2} \mathrm{O}$

Table 2. Unit cell dimensions in Angstrom of the cancrinite from Greenland

\begin{tabular}{lll}
\hline & \multicolumn{1}{c}{$a$} & \multicolumn{1}{c}{$c$} \\
\hline Greenland & 12.708 & 5.191 \\
Cancrinite $^{1}$ & 12.615 & 5.127 \\
Vishnevite Urusai $^{1}$ & 12.51 & 5.08 \\
Vishnevite Vishnevy Gory $^{2}$ & 12.685 & 5.179 \\
Davyne $^{1}$ & 12.70 & 5.33 \\
\hline
\end{tabular}

Cancrinite from Bancroft, Ontario, Canada, vishnevite from Urusai, Altai Ridge and Vishnevy Gory, Russia and davyne from Vesuvius, Italy.

1. The JCPDS powder diffraction Standard File 1989.

2. Hassan \& Grundy, 1984. and the vishnevite end-member

$(\mathrm{Na}, \mathrm{Ca}, \mathrm{K})_{6-7} \mathrm{Al}_{6} \mathrm{Si}_{6} \mathrm{O}_{24}\left(\mathrm{SO}_{4}, \mathrm{CO}_{3}, \mathrm{Cl}\right)_{1.0-1.5} \cdot \mathrm{H}_{2} \mathrm{O}$.

Electron microprobe analyses of the Greenland cancrinite are shown in Table $1 . \mathrm{CO}_{2}$ and $\mathrm{H}_{2} \mathrm{O}$ were determined with a Perkin-Elmer $240 \mathrm{CHN}$ analyser at the H. C. Ørsted Institute, Copenhagen University, as $0.21 \% \mathrm{CO}_{2}$ and $2.82 \% \mathrm{H}_{2} \mathrm{O}$. The low $\mathrm{CO}_{2}$ value and the high $\mathrm{SO}_{3}$ value point to the vishnevite end of the series.

The cell dimensions of the Greenland material resulting from X-ray investigation with a Phillips powder diffractometer, using least squares refinement of 36 powder diffraction lines are shown in Table 2 together with the cell dimensions of cancrinite from Bancroft, Ontario, Canada, vishnevite from Urusai, Altai Ridge, Russia and davyne from Vesuvius, Italy taken from the JCPDS powder diffraction Standard File 1989, and cell dimensions of vishnevite from Vishnevy Gory, Russia from Hassan \& Grundy (1984). These three minerals all crystallise in the hexagonal system.

Comparison of the $a$ and $c$ cell dimensions of the Greenland material with the values of vishnevite in the JCPDS Standard File indicates a considerable disparity. The $a$ value of davyne is close to the Greenland material, but the $c$ value is far too high. Therefore, according to the $\mathrm{X}$-ray investigation and the JCPDS Standard File the material from Greenland is best termed cancrinite. However, the cell dimensions of the Greenland material are closer to vishnevite from Vishnevy Gory than to cancrinite from Bancroft.

Tröger (1982) divides the cancrinite-vishnevite solid solution series into three groups: cancrinite with $0-30$ molecular percent $\mathrm{SO}_{3}$, sulphatic cancrinite with $30-70$ percent $\mathrm{SO}_{3}$, and vishnevite with $70-100$ percent $\mathrm{SO}_{3}$. 
Table 3. Trace element analysis by optical emission spectography (OES-DC-arc) in ppm

\begin{tabular}{lccc}
\hline & Litchfield, USA & Bancroft, Canada & Greenland \\
\hline $\mathrm{Ba}$ & 300 & 800 & 920 \\
$\mathrm{Co}$ & $<5$ & $<5$ & $<5$ \\
$\mathrm{Cr}$ & 30 & $\leq 10$ & $\leq 10$ \\
$\mathrm{Cu}$ & 2 & 4 & 6 \\
$\mathrm{Fe}$ & 580 & 80 & 900 \\
$\mathrm{Ga}$ & 17 & 19 & 14 \\
$\mathrm{Mg}$ & 900 & 1000 & 1400 \\
$\mathrm{Mn}$ & 600 & 160 & 6 \\
$\mathrm{Nb}$ & 15 & 20 & 15 \\
$\mathrm{Ni}$ & $<3$ & $<3$ & $<3$ \\
$\mathrm{~Pb}$ & 20 & $<10$ & $<10$ \\
$\mathrm{Sn}$ & 300 & $<1$ & $<1$ \\
$\mathrm{Sr}$ & 850 & 1200 & 1700 \\
$\mathrm{~V}$ & $<0.8$ & $<0.8$ & $<0.8$ \\
$\mathrm{Zr}$ & $<8$ & $<8$ & 10 \\
\hline
\end{tabular}

The elements were determined by H. J. Bollingberg using a Hilger Large Quartz/Glass Spectrograph and synthetic standards calibrated against G-1, W-1 and NSB minerals with less than $10 \%$ relative standard deviation. Duplicate determinations were made on all samples.

Taken at face value the low $\mathrm{CO}_{2}$ suggests the mineral to be vishnevite. The $\mathrm{H}_{2} \mathrm{O}$ content is reasonable but the $\mathrm{CO}_{2}$ and the sums appear too low. The $\mathrm{CO}_{2}$ analysis was made on powder material that may not correspond to the microprobe analyses. Assuming sums of 100 and a water content of 2.82 the analyses leave room for $2.67-3.43 \% \mathrm{CO}_{2}$ corresponding to 0.317 to 0.411 mole proportions $\mathrm{CO}_{2}$. With such $\mathrm{CO}_{2}$ contents the mineral would straddle the boundary between sulphatic cancrinites and vishnevite. Tröger (1982) also gives a diagram for the variation in density, birefringence and refractivity of omega and epsilon with the content of $\mathrm{SO}_{3}$. All these four values for the Greenland material fall in the field of sulphatic cancrinite.

Deer, Howie \& Zussman (1963) proposed a division of the cancrinite-vishnevite series into four groups: cancrinite containing between 100 and 80 percent of the cancrinite end-member, sulphatic cancrinite with 80 to 50 percent, carbonate vishnevite with 50 to 20 percent, and vishnevite with 20 to 0 percent of the cancrinite endmember. With the estimated $\mathrm{CO}_{2}$ contents the mineral would be a carbonate vishnevite.

The cancrinite end-member is given as

$(\mathrm{Na}, \mathrm{Ca})_{7.8} \mathrm{Al}_{6} \mathrm{Si}_{6} \mathrm{O}_{24}\left(\mathrm{CO}_{3}, \mathrm{SO}_{4}, \mathrm{Cl}\right)_{1.5-2,0} \cdot 1-5 \mathrm{H}_{2} \mathrm{O}$

and the vishnevite end-member as

$(\mathrm{Na}, \mathrm{Ca}, \mathrm{K})_{6} 7 \mathrm{Al}_{6} \mathrm{Si}_{6} \mathrm{O}_{24}\left(\mathrm{SO}_{4}, \mathrm{CO}_{3}, \mathrm{Cl}\right)_{1.0} 1.5 \cdot 1-5 \mathrm{H}_{2} \mathrm{O}$.

The sum of mono- and divalent cations in the cancrinite end-member is between 7 and 8, thus we could consider 80 percent end-member cancrinite as having a sum of mono- and divalent cations of 7.8. The sum of mono- and divalent cations in the Greenland material is 7.8, 7.8 and 7.7 respectively. Thus it is seen that the Greenland material just reaches the cancrinite field.

Another method to distinguish between cancrinite and vishnevite is the ratio of $\mathrm{Na}_{2} \mathrm{O}$ to $\mathrm{K}_{2} \mathrm{O}$ which is high for cancrinite and low for vishnevite. Of the four analyses of cancrinite given in Deer, Howie \& Zussman (1963) one has a $\mathrm{Na}_{2} \mathrm{O} / \mathrm{K}_{2} \mathrm{O}$ ratio of 8 while the three others all exceed 29 , whereas the vishnevite analysis has a ratio of 3. The three electron microprobe analyses of the Greenland material have ratios of 23.6, 25.2 and 27.7 respec-
Fig. 5. Close up of coarse grained nepheline syenite dyke containing blue cancrinite as alteration product of nepheline and late stage interstitial material.

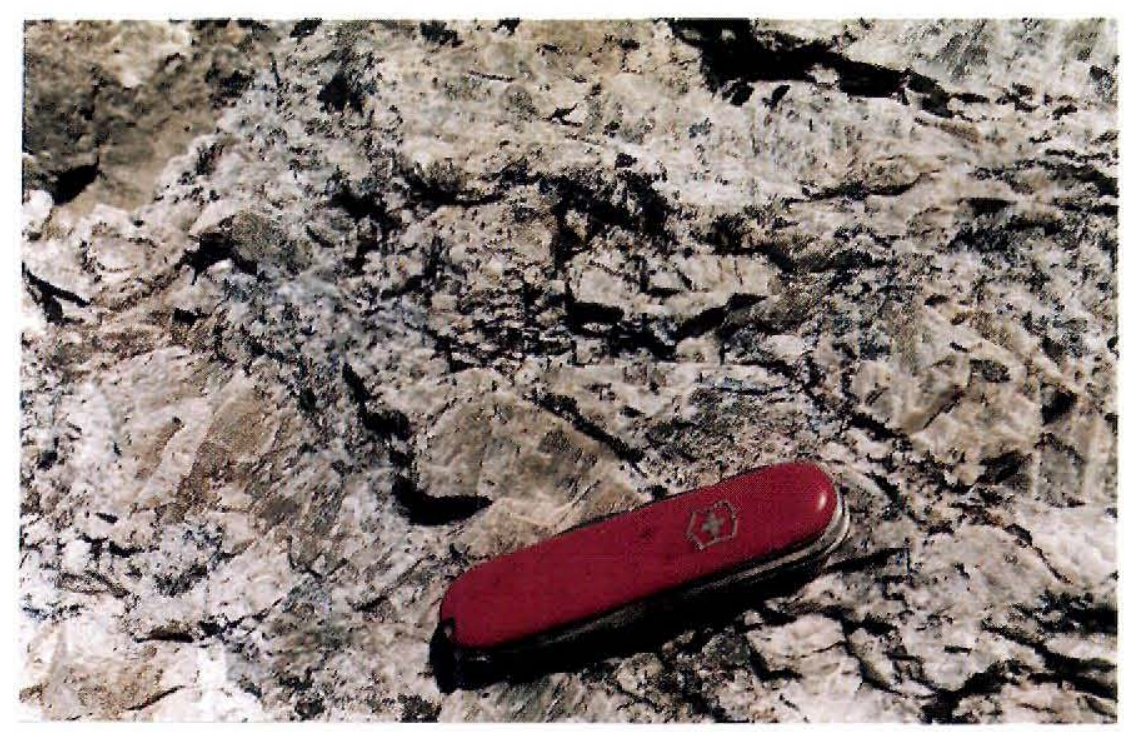


tively which points strongly to cancrinite. The overall conclusion is that the mineral is a sulphatic cancrinite.

Table 3 shows the results of spectral analyses of the cancrinite from Greenland as well as of cancrinite from Bancroft and Litchfield. During the preparation for spectral analysis it was detected that the blue colour of the Greenland cancrinite disappears when the mineral is finely ground, therefore the blue colour is probably purely optical.

\section{Commercial aspects}

The light blue colour of the cancrinite is very attractive and the compact mass of cancrinite and sodalite allows the cutting of cabochons several centimetres across (Fig. 4). The stones take a good polish (with care the stone can be polished to great 'shine') and the cancrinite of the 'Singertat' complex is believed to be a possible source for small scale production of cabochons etc. Reliable information on the amount of material and technical aspects of cutting and polishing are necessary before any commercial evaluation can be made. It is at present believed that the exposed cancrinite-rich rock amounts to no less than $200 \mathrm{~kg}$.

The common occurrence of small amounts of blue cancrinite in many of the syenite dykes and pegmatites (Fig. 5), however, suggests that the formation of blue cancrinite is common in the syenitic pegmatites of the complex and that massive blue cancrinite rock might also be found in other dykes and pegmatites.
Acknowledgments. The authors are grateful to J. Lautrup, Geological Survey of Greenland, for photographing the raw and polished cancrinite. The JEOL Superprobe on which the electron microprobe analyses were carried out was purchased with funds from the Danish Natural Science Research Council, and is operated under the supervision of J. Rønsbo, Geological Institute, University of Copenhagen, whose assistance with the analyses is greatly appreciated. Thanks are also due to E. S. Leonardsen, Geological Institute, University of Copenhagen, for undertaking the $\mathrm{X}$-ray investigation, and to Haldis J. Bollingberg, who undertook the spectral analyses at the Geological Institute, University of Copenhagen. The $\mathrm{CO}_{2}$ and $\mathrm{H}_{2} \mathrm{O}$ analyses were performed by Hans Bengtsson, Geological Institute, University of Copenhagen. Mineral separation of the material from these analyses was performed by Peter Venslev, Geological Institute, University of Copenhagen. Valuable information concerning the field occurrence was obtained from Minik T. Rosing, Geological Museum, Copenhagen.

\section{References}

Deer, W. A., Howie, R. A. \& Zussman, J. 1963: Rock forming minerals 4, Framework silicates. London: Longmans, Green and Co.

Escher, J. 1990: Geological map of Greenland, Sheet 14, Skjoldungen. Copenhagen: Grønlands Geologiske Undersøgelse.

Hassan, I. \& Grundy, H. D. 1984: The character of the cancrinite-vishnevite solid-solution series. Can. Miner. 22, 333 340 .

Nielsen, T. F. D. \& Rosing, M. T. 1990: The Archaean Skjoldungen Alkaline Province, South-East Greenland. Rapp. Grønlands geol. Unders. 148, 93-100.

Tröger, W. E. 1982: Optische Bestimmung der gesteinsbildenden Minerale, Teil 1. Bestimmungstabellen, 5. neubearbeitete $\mathrm{Au}-$ flage. Stuttgart: E. Schweizerbart'sche Verlagsbuchhandlung. 